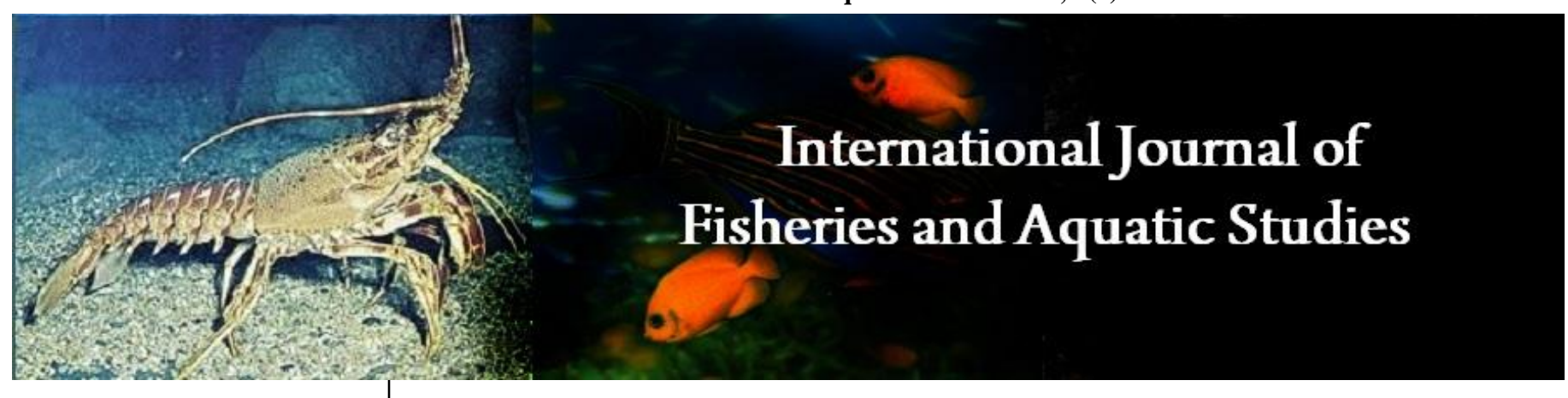

E-ISSN: 2347-5129

P-ISSN: 2394-0506

(ICV-Poland) Impact Value: 5.62

(GIF) Impact Factor: 0.549

IJFAS 2021; 9(2): 180-184

(C) 2021 IJFAS

www.fisheriesjournal.com

Received: 13-01-2021

Accepted: 18-02-2021

\section{Krishna PV}

Department of Zoology and

Aquaculture, Acharya

Nagarjuna University,

Nagarjuna Nagar,

Andhra Pradesh, India

\section{Sai Mounika}

Department of Zoology and

Aquaculture, Acharya

Nagarjuna University,

Nagarjuna Nagar,

Andhra Pradesh, India

\section{BVL Aradhya Sarma}

Department of Zoology and

Aquaculture, Acharya

Nagarjuna University,

Nagarjuna Nagar,

Andhra Pradesh, India

\section{B Padmaja}

DNR College, Bhimavaram,

West Godavari, Andhra Pradesh, India
Corresponding Author: Krishna PV

Department of Zoology and

Aquaculture, Acharya

Nagarjuna University,

Nagarjuna Nagar,

Andhra Pradesh, India

\section{Health risk assessment of heavy metal accumulation in the food fish, Channa striata from Krishna river, Andhra Pradesh}

\author{
Krishna PV, M Sai Mounika, BVL Aradhya Sarma and B Padmaja
}

DOI: https://doi.org/10.22271/fish.2021.v9.i2c.2448

\begin{abstract}
The new threats to human health from heavy metals are associated with exposure to some selected metals. The study identifies and assessment of the accumulation and levels of five heavy metals $(\mathrm{Cd}, \mathrm{Cr}$, $\mathrm{Ni}, \mathrm{Pb}$ and $\mathrm{Zn}$ ) in food fish Channa striata of Krishna river, collected from three stations during four seasons of the year i.e June,2019- May 2020. The range of metal concentrations recorded were: Cd 1.123.35, Cr 1.41-2.89, Ni 1.51 -3.72, $\mathrm{Pb} 3.29-7.69$ and $\mathrm{Zn} \mathrm{13.8-29.1} \mathrm{in} \mathrm{case} \mathrm{of} \mathrm{muscle} \mathrm{and} \mathrm{in} \mathrm{case} \mathrm{of} \mathrm{liver}$ goes to $\mathrm{Cd} 2.21$ - 4.43, Cr 1.74- 3.68, Ni 1.96-3.71, Pb 3.52- 8.09 and $\mathrm{Zn} \mathrm{14.5} \mathrm{-} \mathrm{32.6.} \mathrm{The} \mathrm{spatial}$ variation in concentrations and comparison among seasons indicated that there are significant differences in the concentrations of metals in the muscle and liver for all seasons. The mean metal concentrations varied temporally; metal masses were relatively constant with fluctuations in metal concentrations related to fluctuations in metal body burdens. The metal contamination had significantly higher in both the tissues of $\mathrm{Zn}$ and $\mathrm{Pb}$ concentrations. According to the guideline values, the concentrations of metals studied do not pose any threat to the health of fish consumers.
\end{abstract}

Keywords: heavy metals accumulation. fish, human health risk

\section{Introduction}

Heavy metals are stable and persist environmental contaminants of aquatic environments and their organisms. They occur in the environment both as a result of natural processes and as pollutants from human activities ${ }^{[1]}$. The rapid growth of developmental activities in recent time has created important environmental challenges for human beings and these environmental changes has become an integral part of modern life of human beings [2]. Typically, pollutants are aterials/substances that affect the physical, chemical and biological characteristics of biotic components of the ecosystem as well as the abiotic constituents, thereby posing a threat to human health, animals and plants ${ }^{[2]}$. According to Krishna et al.., ${ }^{[3]}$ metal occur in less than $1 \%$ of the earth's crust, with trace amounts generally found in the environment and when these concentrations exceed a stipulated limit, they may become toxic to the surrounding environment and when these concentrations exceed a stipulated limit, they may become toxic to the surrounding environment. Rivers are contaminated due metal pollution from anthropogenic and industrial activities. Unfortunately, these contaminants may then pass into the food chain causing toxic effects to human health (Krishna et al ${ }^{[4-7]}$. Adverse effects on the river environment highly polluted due to anthropogenic, organic and other developmental activities ${ }^{[2]}$. The discharge of these wastes without adequate treatment often contaminate the river waters with conservative pollutants (like heavy metals), many of which accumulate in the tissues of the resident organisms like fishes and other aquatic organisms. To a larger extent, pollution is caused in developing nation due to inadequate or improper waste management strategies. Wastes are generated in all sector of any nation's economy in large chunks. The unsafe waste disposal is a threat to the ambient environmental condition. Three wastes streams exist including solid wastes (plastic, remains of food processing, agricultural residues), liquid (effluents from industries, food sector etc) and gaseous emissions (pollutant gases from processing or manufacturing sector). 
Fish, as human food, is considered as source of protein, polyunsaturated fatty acids particularly omega-3 fatty acids, \& minerals like Calcium, Zinc and Iron ${ }^{[8]}$. And it is considered one of the high nutrient sources for humans that contribute the lower the blood cholesterol and reduce the risk of stroke and heart diseases $[9,10]$. Murrels is not only the healthy diet to eat and relish but are often utilized as medicine for various diseases ${ }^{[11]}$. It is a one of the most common food fish among the local population with traditionally identified pharmacological benefits in treating wound and pain and in boosting energy of the diseased person. Murrels are fully explored source of medicines, despite they are well known ingredients for many popular medicines and also recognized by current and past pharmacopoeias around the world ${ }^{[12]}$.

The fish Channa striata carnivorous and consumes fish larvae, earthworms, Insect larva and tad poles [13]. The popularity of $C$. striata as a therapeutic agent is related to folk belief in its efficacy in treating wounds, relieving pain and boosting energy, and herein lead to the, patients recovering from surgical operations ${ }^{[13]}$. This fish has high quality food sources and they are playing high role of functional foods, which provide health benefit beyond basic nutrition ${ }^{[14]}$. It is a good source of medicinal food because it contains high level of amino acids and fatty acids. Amino acids might have contributed to its pharmacological properties because the fish include glycine, lysine and araginine, whereas its fatty acids are arachidonic acid, plamitic acid and docosahexaenoic acid $[15,16]$. Extracts of the fish are produced from whole muscle, skin and mucus of the fish. They appear to effect their influences through the formation of several types of bioactive molecules ${ }^{[14]}$. Channa stritata fish extract could improve the cosmetic appearance of wounds and achieve better patient satisfaction [17]. Among the aquatic fauna, fish is most susceptible to heavy metal contamination than any other aquatic fauna. It is well known that fish are good indicator of chemical pollution and as a result they long been used to monitor metal pollution in river and marine environment ${ }^{[7]}$. So, the fishes were considered as better specimens for use in the investigation of metal pollution load than the water sample because of the significant levels of metals they bio accumulate. Hence, harmful substances like heavy metals, released by anthropogenic activities will be accumulated in marine organisms through the food chain; as result, human health can be at risk because of consumption of fish contaminated by toxic chemicals.

Keeping in view of the potential toxicity, persistent nature, as well as the environmental pollution, it is deemed necessary to have the base line environmental data on potential metal contamination so that pollutants can be judged in the environment. This paper presents the data of heavy metal ( $\mathrm{Zn}$, $\mathrm{Pb}, \mathrm{Ni}, \mathrm{Cr}$ and $\mathrm{Cd}$ concentration in fish,from Channa striata of Krishna river

\section{Materials and Methods}

Fish samples was collected from 3 stations: i.e Station -I fish landing centre at Prakasam barrage, Station -II Thummalapalem and Station -III Ibrahimpatnam. The fish samples transported to the laboratory in ice boxes and stored at $-10^{\circ} \mathrm{C}$ until subjected for future analysis. The fishes were dissected and care was taken to avoid external contaminated to the samples. Rust free stainless steel kit was sterilized to dissect the fishes. Double distilled water was used for making up the sample and for analysis in the Atomic Absorption Spectrophotometer (ASS). The gut content, gill and muscles were separated and dried to constant weight and both wet and dry weight recorded. $25 \%$ was used as blank samples accompanied every run of the analysis. Each sample was analyzed in triple to ensure accuracy and precession for the analytical procedure.

$$
\text { Estimated daily intake }(\mathrm{EDI}): \frac{\mathrm{EDI}=\mathrm{E}_{\mathrm{F}} \times \mathrm{E}_{\mathrm{D}} \times \mathrm{F}_{\mathrm{IR}} \times \mathrm{C}_{\mathrm{f}} \times \mathrm{C}_{\mathrm{m}}}{\mathrm{W}_{\mathrm{AB}} \times \mathrm{T}_{\mathrm{A}}} \times 10^{-3}
$$

$\mathrm{E}_{\mathrm{F}}=$ The exposure frequency 365 days/year

$E_{D}=$ The exposure duration, equalent to average life time (65 years)

$\mathrm{F}_{\mathrm{IR}}=$ The fresh food ingestion rate $(\mathrm{g} /$ person/day) which is considered to be India

55/g/person/day. [18]

$\mathrm{C}_{\mathrm{f}}=$ The conversion factor $=0.208$

$\mathrm{C}_{\mathrm{m}}=$ The heavy metal concentration in food stuffs $\mathrm{mg} / \mathrm{kg} \mathrm{d}$ $\mathrm{w})$

$\mathrm{W}_{\mathrm{AB}}$ average body weight (bw) (average body weight to be $60 \mathrm{~kg})$

$\mathrm{TA}=$ Is the average exposure of time for non carciniges (It is equal to $\left(\mathrm{E}_{\mathrm{F}} \times \mathrm{E}_{\mathrm{D}}\right)$ as used by in many previews studies ${ }^{[19]}$

Target hazard quatent:

$$
T H Q=\frac{E D I}{\text { Rfd }}
$$

\section{Rfd: Oral reference dose ( $\mathrm{mg} / \mathrm{kg}$ bw/day)}

A THQ below 1 means the exposed population is unlikely to experience obviously adverse effects, whereas a THQ above means that there is a chance of non-carcinogenic effects, with an increasing probability as the value increases.

\section{Results and Discussion}

The purpose of this work to determined the presence of a particular group of metals in the Channa striata of the Krishna River area. Heaving record to the possibility of bioaccumulation of these metals in tissues of fish it was necessary to find out whether the metals determined in the samples were to be accumulated in the fish ts), the risk imposed on a local population was evaluated. The research presented herein had been conducted in the determination heavy metals concentration of Muscle and liver sample of Channa striata of Krishna river. The mean concentrations of heavy metal in fish muscle and liver are presented Table No. 1 and 2. The order of heavy metal concentration was $\mathrm{Zn}>\mathrm{Pb}>\mathrm{Ni}>\mathrm{Cd}>\mathrm{Cr}$.

\section{Zinc (Zn)}

Zinc is an essential element in animal's diet but it is regarded as potential hazard for both animals and human health ${ }^{[20]}$. Zinc is present in natural water only as a miner consultant because lack of solubility of free metal and its oxides ${ }^{[21]}$. It is a very high concentration only it may causes some toxic effects. A normal human body contains 1.4 to $2.3 \mathrm{~g}$ of Zinc. Recommend daily dietary intake of Zin is about $15 \mathrm{mg}$ for adults and $10 \mathrm{mg}$ for children over a year old. The average diary intake of zinc is India is about $16.1 \mathrm{mg}{ }^{\text {[22] }}$ (Krishnan, 1995). It is relatively non toxic and concentrations of zinc up to $25 \mathrm{mg} / \mathrm{l}$ have shown few adverse effects ${ }^{[23]}$. Zinc may be toxic aquatic organisms but the degree of toxicity varies greatly, depending on water quality characteristics as well as species being considered ${ }^{[24]}$. The present study shows that the 
average concentration of muscle goes to 13.8 to 29.1 and liver goes to 14.5 to $32.6 \mathrm{mg} / \mathrm{kg}$ of $\mathrm{Zn}$ much higher than WHO standards ${ }^{[25]}$.

\section{Lead $(\mathbf{P b})$}

$\mathrm{Pb}$ is considered as a toxic but non-essential metal implying that it has no known function in the biochemical processes ${ }^{[26]}$. Lead enters the aquatic environment through soil erosion and leaching gasoline combustion, municipal and industrial wastes and runoff ${ }^{[27]}$. Pregnant women exposed to lead were found to have high rates of still births and miscarriages ${ }^{[28]}$. Lead has caused mental retardation among children. Hyper tension caused by $\mathrm{Pb}$ exposure has also been reported [29]. Lead poising is a accompanied by symptoms of intestinal cramps, peripheral nerve paralysis anaemia, and fatigue ${ }^{[30]}$. The concentration of lead in natural water increases mainly through anthropogenic activities ${ }^{[31]}$.

In the present study $\mathrm{Pb}$ concentration goes to 3.29 to 7.69 $\mathrm{mg} / \mathrm{kg}$ in the muscle and the liver goes to 3.52 to $8.09 \mathrm{mg} / \mathrm{kg}$. According to WHO [25] the maximum accepted limit is $2 \mathrm{mg} / \mathrm{kg}$ for food fish. The present results indicated that the concentration levels of $\mathrm{Pb}$ was mostly higher than the permissible limits set for human consumption by various regulatory agencies and therefore indicated possible health risks associated with consumption of these fish. At high levels of $\mathrm{Pb}$ exposure these is damaged to almost all organ systems. Most importantly the central nervous system kidneys, and blood, culminating in death, if levels are excessive. At low levels, heame synthesis and other biochemical processes are affected and psychological and neurobehavioral functions are impaired ${ }^{[31]}$.

\section{Nickel(Ni)}

Nickel is a ubiquitous trace metal and occurs in soil, water, air, and in the biosphere. It is emitted into the environment from both natural and man-made sources. Nickel is released during nickel mining and by industries that convert scrap or new nickel into alloys or nickel compounds or by industries that use nickel and its compounds. These industries may also discharge nickel in wastewater. Nickel is also released by oilburning power plants, coal-burning power plants and trash incinerators ${ }^{[33]}$. Once released to the environment, nickel readily forms complexes with many ligands, making it more mobile than most heavy metals ${ }^{[34]}$.

\section{Cadmium (Cd)}

Cadmium production, consumption and emissions to the environment have increased dramatically during the 20th century, due to its industrial use (batteries, electroplating, plastic stabilizers, pigment), and consequently lead to contamination of aquatic habitats ${ }^{[35]}$. The use of cadmium containing fertilizer, agricultural chemicals, pesticides and sewage sludge in farm land, might also contribute to the contamination of water. As a nondegradable cumulative pollutant, $\mathrm{Cd}$ is considered capable of altering aquatic tropic levels for centuries ${ }^{[36-38]}$. Cadmium is toxic element which shows their carcinogenic effect on aquatic biota and humans. It is widely distributed at low levels in the environment and is not an essential element for humans, animals and plants. In the present study Cd shows 1.12 to $3.35 \mathrm{mg} / \mathrm{kg}$ in case of muscle and liver was 2.26 to $4.43 \mathrm{mg} / \mathrm{kg}$.

\section{Chromium (Cr)}

Chromium concentration is natural waters is usually very small. Elevated concentration can result from industrial and mining processes ${ }^{[24]}$. Fish are usually more resistant to $\mathrm{Cr}$ than other aquatic organisms, but they can be affected sublethally where exposed to concentration increases. In the present study $\mathrm{Cr}$ also above permissible levels set by WHO [25].

The present study it was observed that total concentration of $\mathrm{Zn}$ was significantly higher in both organs of when compare with other metals. The differences was noticed in the levels of accumulation in both organs of fish can be attributed to the difference in their physiological roles towards maintaining homeostatic feeding habits, regulatory ability and behaviour of fish ${ }^{[33]}$. The heavy metals causing concern is that they may be transferred and accumulated in the bodies of animals or human beings through food chain, which will probably cause DNA damage and carcinogenic effects due to their mutagenic ability ${ }^{[39]}$. Heavy metal exposure of the population may cause neurobehavioral disorders. Such as fatigue insomnia decreased concentration, depression, irritability, sensory and motor symptoms ${ }^{[40]}$. Exposure to heavy metals has been linked to developmental retardation, various types of cancer, kidney damage, autoimmunity and even death in some instances of exposure to very high concentrations [41]. Cadmium enters into the human body through intake of contaminated foodstuffs such as mush-rooms, liver and sea weeds ${ }^{[35]}$. It gets transported into liver through blood circulation where it binds with metal binding protein metallothionein that sequesters it and transports to the kidney. In kidney, it accumulates and interferes with blood purification mechanisms. It causes kidney and liver damage and deformation of bones ${ }^{[42]}$. Cadmium has been re-ported to be mutagenic, carcinogenic, teratogenic, embryo toxic, hyperglycemic agents and anemia inducing agents and has reduced immuno potency ${ }^{[43]}$.

In some cases fish catches were banned for human consumption because their heavy metal concentrations exceeded the maximum limits recommended by the Food and Agriculture organization (FAO) and world health organization (WHO). Among sea foods, fish are commonly consumed and hence, are a connecting link for the transfer of toxic heavy metals in human beings. Bhuvaneshwari et al., ${ }^{[44]}$ concluded that the metals are an inherent component of the environment that pose a potential hazard to human beings and animals. The consumption of fish from the polluted site may result in accumulation of persistent pollutants in ultimate recent of food web. The effluents from the textile factory, the tannery and the floriculture farm probably contain harmful contaminants such as dye stuffs, bonzothiozole, sulphonated polyphenols and pesticides. These compounds could bioaccumulate and affect the health of aquatic organisms and subsequently, the health of humans, as consumers of these fish ${ }^{[45]}$.

In the fish, we analysed revel some metals concentrations potentially toxic if they enter the food chain. However, since their toxicity for human is given by the ingestion rate, data obtained on THQs values (; $\mathrm{Zn}-1.58$; $\mathrm{Pb}-0.42$; Ni-0.38; Cd0.26 and $\mathrm{Cr}-0.21$ ) indicated that the contractions is found in the sample of fish represent a risk for human are very limited. The THQ is higher than one only in ZN. Of course, it is just a Primary step; fish contamination levels should be carefully monitored on a regular basis, to detect any change in their patterns that could become a hazard on human safety. Similar results observed by Ambedkar and Maniyan, [46]. Adams [47] concluded that the heavy metal concentrations were above the 
maximum levels recommended by regulatory agencies and, depending on daily intake by consumers, might represent a risk for human health.

Table 1: Status of Heavy Metals in Muscle of Channa striata (mg/kg)

\begin{tabular}{|c|c|c|c|c|c|c|c|c|c|c|c|c|}
\hline Metals & \multicolumn{3}{|c|}{ South West Monsoon } & \multicolumn{3}{|c|}{ Post Monsoon } & \multicolumn{3}{|c|}{ North East Monsoon } & \multicolumn{3}{|c|}{ Summer } \\
\hline & St-I & St-II & St-III & St-I & St-II & St-III & St-I & St-II & St-III & St-I & St-II & St-III \\
\hline $\begin{array}{c}\text { Cadmium } \\
{[\mathrm{Cd}]}\end{array}$ & $3.01 \pm 0.21$ & $1.42 \pm 0.03$ & $2.42 \pm 0.18$ & $1.93 \pm 0.13$ & $2.01 \pm 0.6$ & $1.12 \pm 0.04$ & $1.51 \pm 0.08$ & $3.01 \pm 0.21$ & $3.01 \pm 0.21$ & $2.91 \pm 0.85$ & $.75 \pm 0.79$ & $3.12 \pm 0.99$ \\
\hline $\begin{array}{c}\text { Chromium } \\
{[\mathrm{Cr}]}\end{array}$ & $2.71 \pm 0.17$ & $1.51 \pm 0.06$ & $2.11 \pm 0.11$ & $1.96 \pm 0.14$ & $2.35 \pm 0.72$ & $1.44 \pm 0.11$ & $1.41 \pm 0.07$ & $2.71 \pm 0.17$ & $2.71 \pm 0.17$ & $2.53 \pm 0.76$ & $2.45 \pm 0.72$ & $2.83 \pm 0.9$ \\
\hline Nickel [Ni] & $3.21 \pm 0.33$ & $1.51 \pm 0.06$ & $2.33 \pm 0.21$ & $2.54 \pm 0.21$ & $2.57 \pm 0.83$ & $1.49 \pm 0.12$ & $1.63 \pm 0.09$ & $3.21 \pm 0.33$ & $3.21 \pm 0.33$ & $3.15 \pm 0.9$ & $3.42 \pm 1.11$ & $3.37 \pm 1.13$ \\
\hline Lead $[\mathrm{Pb}]$ & $92 \pm 1.33$ & $3.29 \pm 0.45$ & $5.12 \pm 1.01$ & $5.15 \pm 1.23$ & $5.61 \pm 1.35$ & & $3.59 \pm 0.44$ & & $6.92 \pm 1.33$ & $5.79 \pm 1.2$ & $5.98 \pm 1.3$ & $5.95 \pm 1.26$ \\
\hline Zinc $[\mathrm{Zn}]$ & $27.1 \pm 3.89$ & $14.9 \pm 2.87$ & $22.4 \pm 3.22$ & $23.1 \pm 3.4$ & $23.7 \pm 3.45$ & $13.8 \pm 2.65$ & $13.6 \pm 2.41$ & $27.1 \pm 3.89$ & $27.1 \pm 3.89$ & $25.5 \pm 3.51$ & $27.2 \pm 3.62$ & $29.1 \pm 4.0$ \\
\hline
\end{tabular}

Table 2: Status of Heavy Metals in Liver of Channa striata $(\mathrm{mg} / \mathrm{kg}$ )

\begin{tabular}{|c|c|c|c|c|c|c|c|c|c|c|c|c|}
\hline \multirow[t]{2}{*}{ Metals } & \multicolumn{3}{|c|}{ South West Monsoon } & \multicolumn{3}{|c|}{ Post Monsoon } & \multicolumn{3}{|c|}{ North East Monsoon } & \multicolumn{3}{|c|}{ Summer } \\
\hline & St-I & St-II & St-III & St-I & St-II & St-III & St-I & \begin{tabular}{|l|} 
St-II \\
\end{tabular} & St-III & St-I & St-II & St-III \\
\hline Cadmium [Cd] & $4.21 \pm 0.56$ & $4.02 \pm 0.59$ & $4.43 \pm 0.51$ & $2.21 \pm 0.32$ & $2.31 \pm 0.35$ & $2.01 \pm 0.26$ & $3.21 \pm 0.42$ & $3.05 \pm 0.51$ & $3.33 \pm 0.55$ & $3.9 \pm 0.43$ & $3.52 \pm 0.49$ & $3.96 \pm 0.50$ \\
\hline Chromium [Cr] & $3.11 \pm 0.3$ & $3.22 \pm 0.41$ & $3.68 \pm 0.33$ & $1.74 \pm 0.2$ & $1.62 \pm 0.13$ & $1.79 \pm 0.11$ & $2.33 \pm 0.4$ & $2.46 \pm 0.42$ & $2.61 \pm 0.52$ & $2.99 \pm 0.71$ & $3.11 \pm 0.8$ & $3.5 \pm 0.77$ \\
\hline \begin{tabular}{|l|} 
Nickel [Ni] \\
\end{tabular} & $3.71 \pm 0.66$ & $4.21 \pm 0.71$ & $4.43 \pm 0.67$ & $1.96 \pm 0.2$ & $2.01 \pm 0.23$ & $2.11 \pm 0.32$ & $2.98 \pm 0.18$ & $3.01 \pm 0.21$ & $3.31 \pm 0.46$ & $3.52 \pm 1.09$ & $3.73 \pm 1.15$ & $3.91 \pm 1.21$ \\
\hline Lead $[\mathrm{Pb}]$ & $7.76 \pm 1.12$ & $7.91 \pm 1.2$ & $8.09 \pm 1.26$ & $3.52 \pm 1.07$ & $3.99 \pm 1.17$ & $3.86 \pm 1.14$ & $5.47 \pm 1.22$ & $5.30 \pm 1.19$ & $5.79 \pm 1.32$ & $6.46 \pm 1.56$ & $6.38 \pm 1.42$ & $6.71 \pm 1.82$ \\
\hline Zinc $[\mathrm{Zn}]$ & $29 \pm 3.8$ & $29.9 \pm 3.7$ & $32.6 \pm 3.9$ & $15.4 \pm 3.6$ & $14.6 \pm 3.4$ & $14.5 \pm 3.2$ & $26.2 \pm 4.1$ & $24.1 \pm 3.8$ & $23.1 \pm 3.6$ & $29.9 \pm 4.2$ & $29.5 \pm 4.1$ & $29 \pm 4.0$ \\
\hline
\end{tabular}

\section{Conclusions}

The international official regulatory agencies like WHO have set limits for heavy metal contaminations above which the fish and fishery products are unsuitable for human consumption. However, in the Indian subcontinent there are no safe levels of heavy metal in fish tissues although the Indian population is the major fish consumers in the tropics with a weekly annual rate of $55 \mathrm{~kg} /$ person. Finally, we recommended that a long-term continuous monitoring to check metals pollution, in order to control of metal in water and fish, control and assessment of the metal content in water of Krishna river, which are supplied by water used agriculture, aquaculture, industries (particularly dies factories), quality of water farmlands. In addition, guidance of people and farmers of both agriculture and aquaculture, about the instruction for use of pesticides, chemicals, drugs and control of house wastewater spreading in rivers and crops are necessary.

\section{References}

1. Jordao CP, Pereira MG, Bellato CR, Pereira JL, Matos AT. Assessment of water system for contaminates from domestic and industrial sewages, Environment Monitoring and Assessment 2002;79:75-100.

2. Krishna PV, Swapna CH, Prabhavathi K, Panchakshari V. "Heavy metal accumulation in Channa striata from Kolleru Lake and human health risk assessment". International Journal of Advanced Research 2015;3(8):994-998.

3. Krishna PV, Madhusudhana Rao K, Swarupa Rani V, Srinivas Rao D. Heavy metals concentration in fish Mugil cephalus from Machilipatnam coast and Possible health risks to fish consumers. Brit. Biotech. Jour 2014;4 (2):126-135.

4. Krishna PV, Jyothirmayi V, Madhusudhana Rao K. Human health risk assessment of heavy metal accumulation through fish consumption, from Machilipatnam Coast, Andhra Pradesh, India. Int. Res. Jour. of Public and Environmental Health 2014;1(5):121125.

5. Krishna PV, Prabhavathi K, Prakasa rao R. Potential health risk assessment of heavy metal accumulation in the selected food fishes from Krishna Esturine region of Southern Deltaic Region of India. Current Trends in Biotechnology and Pharmacy 2018;12(3):293-301.

6. Krishna PV, Saleem Basha SK, Glori Sathyavani K, Prabhavathi K. Heavy metal bioaccumulation in the Channa marulius from Lake Kolleru and human health risk assessment. International Journal of Zoology Studies 2018;3(1):76-79.

7. Krishna PV, Madhusudhana RK. Levels of the Heavy Metals in Tissues of wild brush toothed lizard fish "Saurida undosq-uamis" from Nizampatnam Coast, Andhra Pradesh: Possible Health Risk. BIOINFO Environment and Pollution 2013;4(2):72-76.

8. Chan HM, Tritonopoules M, Img A, Receeveur O, Johnson E. Consumption of fresh water fish in Kahn awake: Risks and benefits. Environ. Res. sec 1999;80(2):213-222.

9. Storelli MM. Potential human health risk from metal $(\mathrm{Hg}, \mathrm{Cd}$ and $\mathrm{Pb})$ and polychlorinated biphenyl's ( $\mathrm{PCBC})$ via sea food consumption: Estimation of target hazard quotients (THQs) and toxic equivalent (TEOs). Food and chemical toxicology 2008;46:2782-2788.

10. Al-Busaidi M, Yesudhan P, Al Mughairi S, Al-Rabdi, Al. Harthy WAK, Al Mazrooei KS et al. Toxic metals in commercial marine fish in Oman with reference of national and International standards. Chemosphere 2011;85.67-73.

11. Aminur Rahman M, Arshad A, Nurul Amin SM. Growth and production performance of threatened snakehead fish, Channa striatus (Bloch), at different stocking densities in earthen ponds. Aquacult Res. 2012;201:297302.

12. Abdul Manan, MAT Jais. Pharmacognosy and pharmacology of Haruan (Channa striatus), a medicinal fish with wound healing properties. Boletin Latinoamericano y del Caribe de Plantas Medicinales y Aromaticas 2007;6:52-60.

13. Barakbah A. Ensiklopedia Perbidanan Melayu. Kuala Lumpur: Nona Roguy/Utusan Melayu Publications 2007.

14. MohdShafri MA, Abdul Manan MJ. Therapeutic Potential of the Haruan (Channa striatus): From Food to Medicinal Uses. Malays J Nutr 2012;18:125-136. 
15. Febriyenti, Noor AM, Baie S. Mechanical properties and water vapour permeability of film from haruan (Channa striatus) and fusidic acid spray for wound dressing and wound healing. Pak J Pharm Sci 2010;23:155-159.

16. Shafri MAM, Abdul Manan MJ. "Therapeutic potential of the haruan (Channa striatus): from food to medicinal uses." Malays J Nutr 2012;18:125-136.

17. Quinn JV, Drzewiecki AE, Elmslie TJ. Appearance scales to measure cosmetic outcomes of healed lacerations. Am J Emerg Med 1995;13:229-231.

18. Mitra A, Chowdhury R, Benerjee K. Concentration of some heavy metals commercially important fin fish and shell fish of River Ganga. Environ. Monit. Assess 2012; 184:2219-2230.

19. Wang X, Santo T, Xing B, Tao S. Health risk of heavy metals to the general public in Tianjin, China via consumption of vegetable and fish. Science of the total environment 2005;350:28-37.

20. Amundsen PA, Staldvilk FJ, Lukin A, Kashulin N, Popova O, Restetnikov Y. Heavy metals contaminations in fresh water fish form the border region between Norway and Russia. Science of the total environment 1997;201:211-214.

21. Inyinbor AA, Adekola FA, Abdul Raheem AMO. Heavy metal pollution study of Onyi river in Obajana Community of Kogi State, Nigeria. IOSR Journal of Applied Chemistry 2012;2(3):26-31.

22. Krishnan K. Fundamentals of environmental pollution. Chand. Ltd. 1995, 366.

23. Mc Neely RN, Neimanis VP, Dwyer L. Water quality source book. A guide to water quality parameter, Inland water directorate Water quality Branch, Ohawa. Canada. 1999, 1-65.

24. Datar A, Vashishtha RP. Investigation of heavy metals in water and silt sediments of Bitwa River. Indian journal of environmental protection 1990;10(9):66-672.

25. WHO (World health organization) 1985. Guidelines for drinking water quality Recommendation WHO. Geneva. 1985;1:130.

26. Adeyeye EI, Akinyugha NJ, Fesobi ME, Tenabe VO. Determination of some metals in freshwater pond and their environment. Aquaculture 1996;47:205-214.

27. DWAF (Department of water Affains and Forestry). South African water quality guidelines, aquatic ecosystems 1996;2(7):159.

28. WHO. Technical report series: Trace elements in human nutrition. Report of a WHO expert committee. No.532. Geneva 1973.

29. Beevens DG, Erskine E, Robertson M, Beattle AD, Campbell BC, Goldberg A. Blood lead to hypertension. Lancet 1976;2:1-3.

30. Umar A, Ahmad MS. Hydrogeological and Hydrochemical frame works of regional aquter system in Kali-Ganga sub-basin, India. Environmental Geology. 2001;40(4-5):6-2-611.

31. Goel PK. water pollution causes effects and control. New Delhi, New age 1997.

32. Goldstein GW. Neurological concept of lead poisoning in children. Pediatr. Ann 1992;-21:384-388.

33. Krishna PV, Madhusudhana RK. Levels of the Heavy Metals in Tissues of wild brush toothed lizard fish "Saurida undosq-uamis" from Nizampatnam Coast, Andhra Pradesh: Possible Health Risk. BIOINFO Environment and Pollution 2013;4(2):72-76.
34. Asep Sahidin, Ahmad Fadhilah, Heti Herawati, Herman Hamdani, Sunarto. Heavy metal pollutant traps in the estuarine area: the response of Avicenia marina root to lead pollution in the mangrove tourism of Muara Angke, Jakarta, Indonesia. International Journal of Fisheries and Aquatic Research 2020;5(2):49-54.

35. Jarup L, Hellstrom L, Alfven T, Carlsson MD, Grubb A, Persson B et al. Low level exposure to cadmium and early kidney damage: the OSCAR study. Occupational and Environmen-tal Medicine 2000;57:668-672.

36. Zhang $\mathrm{H}$, Zhang BG, Wang $\mathrm{S}$, Chen J, Xing $\mathrm{Y}$. Spatiotemporal vanadium distribution in soils with microbial community dynamics at vanadium smelting site. Environmental Pollution 2020;265(A):114782.

37. Vieira KS, Crapez MAC, Lima LS, Delgado JF, Brito EBCC, Fonseca EM et al. Evaluation of bioavailability of trace metals through bioindicators in a urbanized estuarine system in southeast Brazil. Environ Monit Assess. 2021;193:18. https://doi.org/10.1007/s10661020-08809-x

38. Zhang $\mathrm{H}$, Zhang BG, Wang $\mathrm{S}$, Chen J, Xing $\mathrm{Y}$. Spatiotemporal vanadium distribution in soils with microbial community dynamics at vanadium smelting site. Environmental Pollution, 2020;265(A):114782.

39. Knasmuller S, Gottmann E, Steinkellner H, Fomin A, Pickl C, Paschke A. Detection of genotoxic effects of heavy metal contaminated soils with plant bioassay. Mutation Research 1998;420:37-48.

40. Hanninen $H$, Lindstrom $H$. Behaviour test battery for toxic psychological studies used at the institute of occupational health in Helsinki. Helsinki: Institute of Occupational Health 1979.

41. Rai PK. Heavy metal phytoremediation from aquatic ecosystems with special reference to macrophytes. Critical Reviews in Environmental Science and Technology 2009;39(9):697-753.

42. Abbas AM, Ismail N, Easa AM. Assessment of arsenic and heavy metal contents in cockles (Anadara granosa) using multivariate statistical techniques. Journal of Hazardous Materials 2008;150:783-789.

43. Rehman A, Sohail AM. Cadmium Uptake by Yeast, Candida tropicalis, Isolated from Industrial Effluents and Its Potential Use in Wastewater Clean-Up Operations. Water, Air \& Soil Pollution 2010;205:149-159.

44. Bhuvaneshwari R, Mamtha N, Paneerselvan, Babu Rajendran R. Bioaccumulation of metals in muscle, Liver and Gills of sex commercial fish species at anaikaraidam of River Kaveri, south India. Internal Journal of Applied Biology and Pharmaceutical Technology 2012;3:18-10.

45. Dsikowitzky L, Mengesha M, Dadebo EDCEV, Sindern S, Dsikowitzky L. Assessment of heavymetals in water samples and tissues of edible fish species from Awassa and koka Rift valley lakes, Ethiopia. Environ-monit. Assess 2013;185:3117-3131.

46. Ambedkar G, Muniyan M. Bioaccumulation of some heavy metals in the selected five freshwater fish from kollidam River, Tamilnadu. India. Advances in Applied Science Research 2011;2(5):221-225.

47. Adams RH, Valeria OC, Francisco JG, GÁ, Verónica ID. Human health risk from fish consumption following a catastrophic gas oil spill in the Chiquito River, Veracruz, Mexico. Environ Monit Assess 2020;192:783. https://doi.org/10.1007/s10661-020-08742-z 